\title{
Preliminary Investigation on the Soil Environment of Contaminated Plots-An Abandoned Plot of A Chemical Plant in the Lower Reaches of Yangtze River
}

\author{
Jiangli Zhu ${ }^{1,2,3}$, Honggui Chen ${ }^{1,2,3 *}$, Xiangmei $\mathrm{Li}^{1,2,3}$ \\ ${ }^{1}$ Sinosteel Ma'anshan General Institute of Mining Research Co., Ltd., \\ Ma'anshan 243000, Anhui, China \\ ${ }^{2}$ The National Engineering Technology Research Center of Solid Waste Treatment and Disposal for Metal Mines, \\ Ma'anshan 243000, Anhui, China \\ ${ }^{3}$ The National Quality Supervision and Inspection Center of Iron Concentrate for Metallurgical Industry, \\ Ma'anshan 243000, Anhui, China \\ *Correspondence Author
}

\begin{abstract}
This paper analyzes the production history and other production activities of the abandoned plot of a chemical plant in the lower reaches of the Yangtze River. Preliminary investigation results showed that the concentration of heavy metals and volatile and semi-volatile pollutants in the soil of the site did not exceed the second-class land screening value standard of the Soil Pollution Risk Control Standards for Construction Land in Soil Environmental Quality (GB36600-2018), so according to related regulations, the plot does not belong to the pollution plot, soil environmental investigations to end. There is no need to carry out detailed soil environment survey and health risk assessment.
\end{abstract}

Keywords: Environmental investigation, Groundwater, Soil environment.

\section{Introduction}

At present, the allocation of existing land resources has become strained due to the strict requirements of the national land use policy[1]. In addition, with China's rapid economic development and the requirements of ecological environmental protection, the development and protection of land resources are becoming increasingly acute. The reconstruction and environmental supervision of the original abandoned land can effectively solve the land dilemma in urbanization development, expand the space for urban development and improve the utilization rate of land[2]. According to the requirements of relevant documents such as Soil Environmental Management Measures for Polluted Land (Trial) (No. 42 of the Ministry of Environmental Protection), Soil Environmental Management Measures for Industrial and Mining Land (Trial) (No. 3 of the Ministry of
Ecology and Environment). In order to prevent the change of land use nature during site reuse and new environmental problems that may occur in the process of redevelopment and utilization, and ensure personal safety, it is necessary to carry out pollution investigation and risk assessment on the site where the abandoned factory is located.

\section{Materials and Methods}

\subsection{Overview of Contaminated Plots}

The abandoned plant of a chemical plant in the lower reaches of the Yangtze River was originally a pyrite sulphuric acid plant. The plant was built in 1998 and put into use, covering an area of 22, $647.35 \mathrm{~m}^{2}$, as shown in Figure 1.

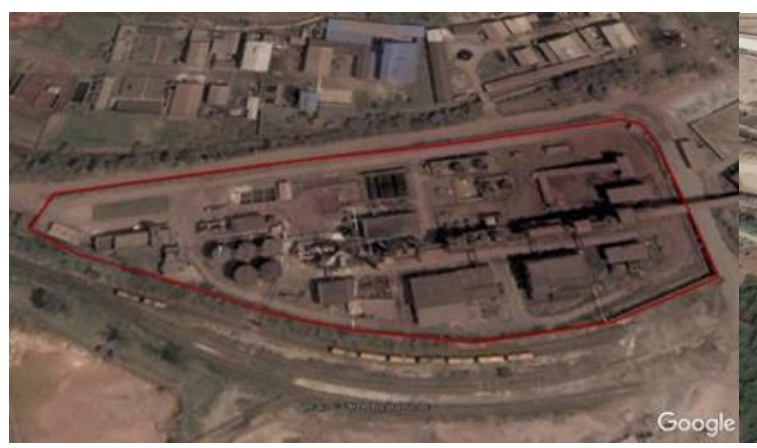

July 29, 2003

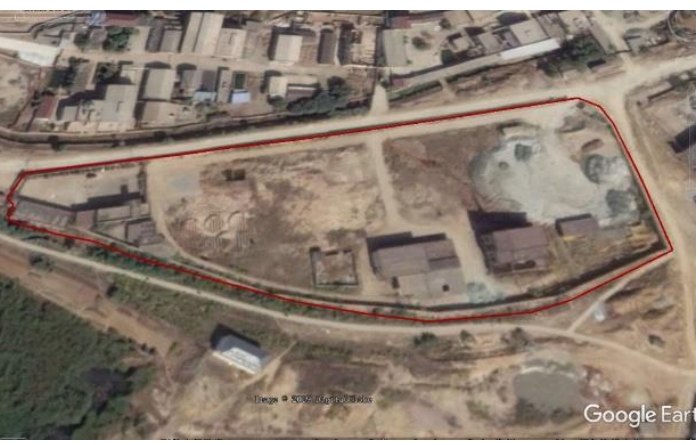

October 19, 2008

Figure 1: Historical satellite images of the site

The area of the site is separated from the surrounding area by walls and roads, and the investigation boundary is clear. After the establishment of the company's main production business for the production and sales of sulfuric acid. The historical satellite images of the site can be traced back to July 2003 at the earliest. During this period, the factory had stopped production, and the buildings and related structures in the site had not been dismantled, so the layout was clear. By October 
2008, the plant equipment has been dismantled, most of the buildings on the site have been dismantled, only part of the buildings can be seen in satellite images. By May 2015, satellite images showed little change in the layout of the site. In 2019, all the building facilities in the site have been demolished, the site has been leveled, and the site has been idle since then. At present, the land is being acquired by the local government and will be re-planned according to the site conditions

\subsection{Spot Sampling and Sample Collection}

According to the first-stage environmental investigation, through the analysis of the production history of the investigation site, the use of main raw and auxiliary materials and products, the main production process, the discharge and treatment of relevant pollutants and other data, as well as the results of site visits and interviews, the suspected pollution of the site was preliminarily confirmed. The main pollution channels are the pollution caused by the pollutant infiltration through the surface during the production process and the accumulation of pollutants, and the cracking and leakage pollution of the waste water pool and the cooling pool. The main suspected contamination areas are production workshops and warehouse areas. Heavy metals (cadmium, chromium (hexavalent), copper, lead, mercury, nickel), arsenic, sulfuric acid, acid sludge, waste residue and other pollutants may exist in the site. Sampling sites are arranged in accordance with the relevant provisions in "Technical Guide for Soil Environment Investigation and Assessment of Construction Land" (Announcement No. 72, 2017 of the Ministry of Environmental Protection), "Technical Guidelines for Site Environmental Investigation” (HJ25. 1-2014), "Technical Guidelines for Site Environmental Monitoring” (HJ25. 2-2014) and the site pollution identification results of the project.

The site for this investigation has stopped production, and all the production workshops and other structures in the site have been removed and the ground has been leveled. The main area layout and historical production activities of the site are relatively clear. For the layout of sampling points in the preliminary investigation, sampling points shall be arranged in the areas suspected to be most polluted in the site by combining zoning and professional judgment. The sampling plan was designed according to the regional characteristics, pollutant characteristics and migration mode of the investigation site. HQZ180L drilling machine will be used for soil sampling. Casing is used to protect the wall while drilling. If the borehole is located on the concrete floor, the concrete floor will be drilled first and then drilled. In the process of drilling, fill in the soil drilling sampling record sheet according to the requirements of the soil drilling sampling record sheet, and take photos of the sampling point, drilling operation, core box, drilling record sheet and other links. A total of 10 soil sampling sites were arranged in this survey, including 1 off-site comparison site (1-S1), 1 office area (1-S5), 2 warehouse areas (2-S1 and 2-S2), and 6 production areas (1-S2, 1-S3, 1-S4, 2-S3, 2-S4). At each monitoring site, 2-3 soil samples were collected at different depths, and a total of 24 samples were taken.
In addition, because the site is part of the water area, decorate this survey, a total of four sample point of groundwater, which contains two suspected pollution monitoring stations (W1, $\mathrm{W} 3,1$ original warehouse area, the original production area 1), the position of pollution of groundwater flow to downstream of 2 (W5, W6, 1 original warehouse area downstream, the original production area downstream 1). One sample was collected at each monitoring point, and a total of 4 samples were taken. FIG. 3 shows the distribution of sampling points. According to the analysis of the existing data in the pollution identification stage, the possible pollutants involved in the site include the pollution generated by various materials used in the production process, equipment oil, products and boiler operation. The main characteristic pollutants include heavy metals, VOC and SVOC.

There were 48 soil detection indexes, including 8 heavy metals, 28 volatile organic compounds and 11 semi-volatile organic compounds. In addition, soil $\mathrm{pH}$ value should be tested to understand soil $\mathrm{pH}$ and soil moisture should be tested to understand soil moisture. There are 16 detection indexes of groundwater, including 7 heavy metals, 1 chlorinated organic matter, 1 total hardness, 1 soluble total solids, 1 sulfate, 1 permanganate index (oxygen consumption), 1 ammonia nitrogen, 1 sodium. In addition, in order to understand the $\mathrm{pH}$ value of groundwater, it is necessary to test the $\mathrm{pH}$ value of groundwater. Test items and standards are shown in Table 2.

Table 1: Summary of site survey plan

\begin{tabular}{|c|c|c|c|}
\hline Project & NO. & Sampling depth (m) & $\begin{array}{r}\text { Number of } \\
\text { sampling }\end{array}$ \\
\hline \multirow{2}{*}{ Soil } & $\begin{array}{l}\text { 1-S1,1-S2, 1-S3, } \\
1-\mathrm{S} 4,1-\mathrm{S} 5,1-\mathrm{S} 6\end{array}$ & $0-0.5 \mathrm{~m}, 1.5-2.0 \mathrm{~m}$ & 12 \\
\hline & $\begin{array}{c}2-\mathrm{S} 1,2-\mathrm{S} 2,2-\mathrm{S} 3 \\
2-\mathrm{S} 4\end{array}$ & $\begin{array}{c}0-0.5 \mathrm{~m}, 5.5-6.0 \mathrm{~m}, \\
6.5-7.0 \mathrm{~m}\end{array}$ & 12 \\
\hline $\begin{array}{l}\text { Underground } \\
\text { water }\end{array}$ & W1,W3, W5, W6 & $\begin{array}{c}\text { Underground water } \\
\text { level below } 0.5 \text { meters }\end{array}$ & 4 \\
\hline
\end{tabular}

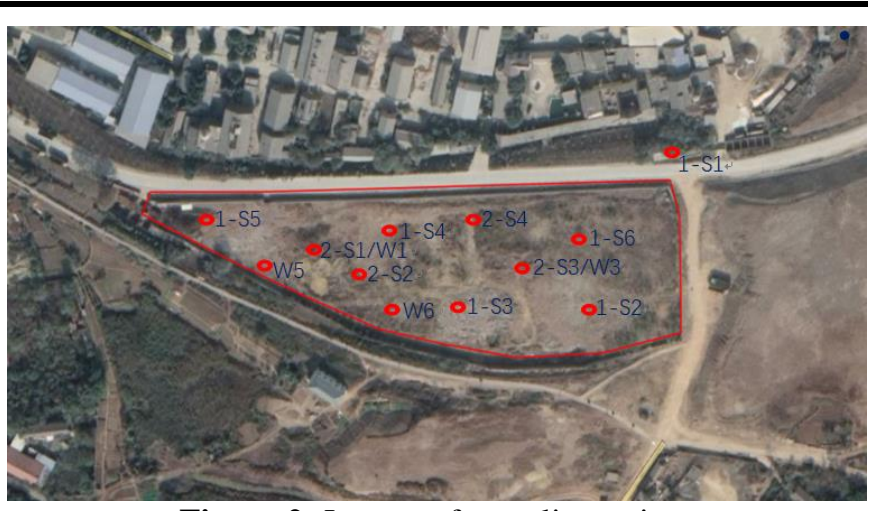

Figure 2: Layout of sampling points

Table 2: List of test items and standards Detection factor $\quad$ Analysis methods and data $\quad$ Detection limit $\mathrm{pH}$

Glass electrode 0.01(Dimension methodNY/T1377-2007 less)

2. Heavy metals and inorganic substance GB/T22105.2-2008 Atomic fluorescence spectrometry GB/T17141-1997graphite $0.02(\mathrm{mg} / \mathrm{kg})$ 


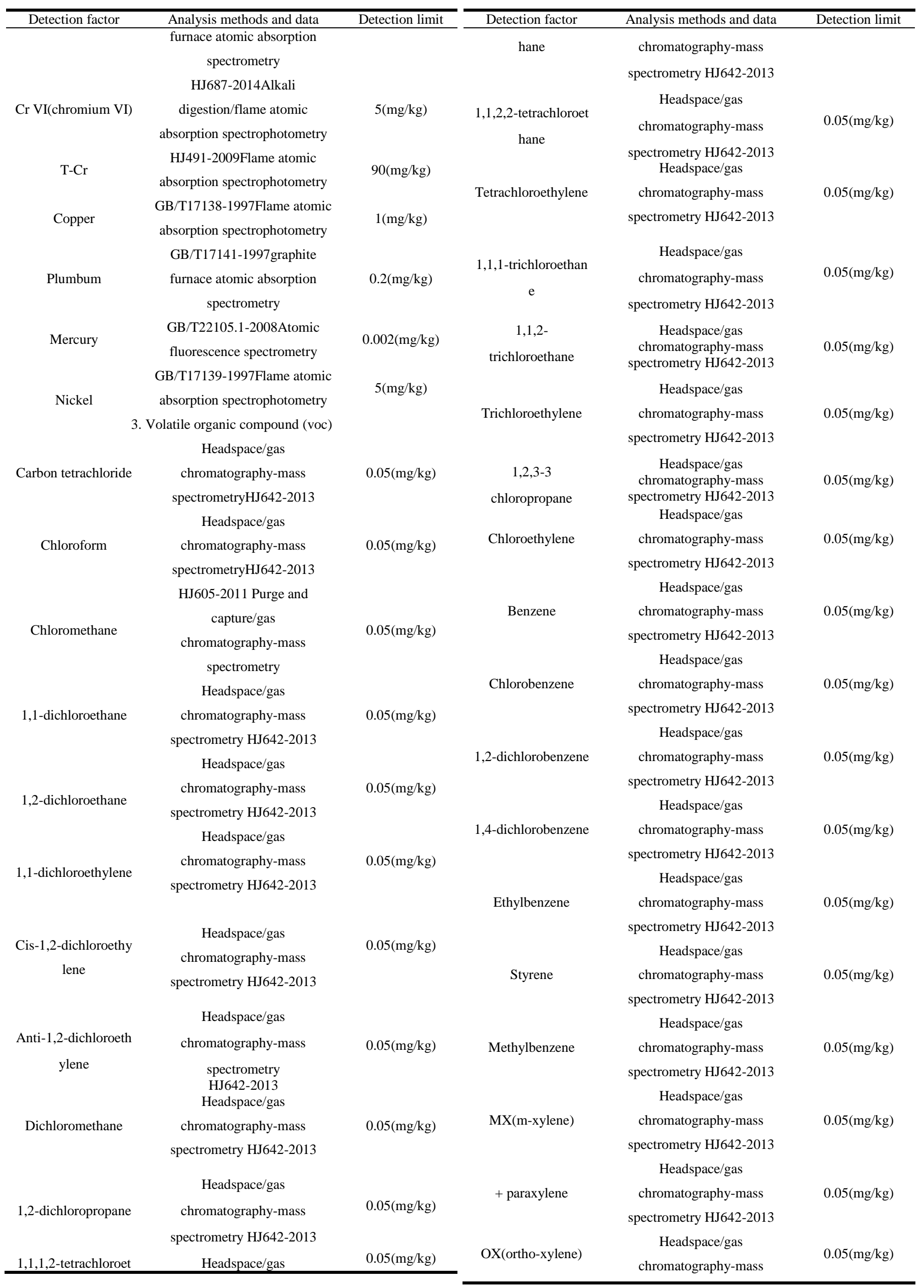




\begin{tabular}{|c|c|c|}
\hline Detection factor & Analysis methods and data & Detection limit \\
\hline & spectrometry HJ642-2013 & \\
\hline \multicolumn{3}{|c|}{ 4. semi-volatile organic compound } \\
\hline \multirow{2}{*}{ Nitrobenzene } & USEPA8270Rev.4(2007.2) & \multirow{2}{*}{$0.05(\mathrm{mg} / \mathrm{kg})$} \\
\hline & Semi volatile organic compound & \\
\hline \multirow{2}{*}{ Aniline } & USEPA8270Rev.4(2007.2)Semi & \multirow{2}{*}{$0.05(\mathrm{mg} / \mathrm{kg})$} \\
\hline & -volatile organic compounds & \\
\hline \multirow{2}{*}{ 2-chlorophenol } & gas chromatographic & \multirow{2}{*}{$0.05(\mathrm{mg} / \mathrm{kg})$} \\
\hline & methodHJ703-2014 & \\
\hline $\operatorname{Dibenzo}(\mathrm{A}, \mathrm{H})$ & Gas chromatography-mass & \multirow{2}{*}{$0.05(\mathrm{mg} / \mathrm{kg})$} \\
\hline anthracene & spectrometry HJ805-2016 & \\
\hline \multirow{2}{*}{ Benzo [a] pyrene } & Gas chromatography-mass & \multirow{2}{*}{$0.05(\mathrm{mg} / \mathrm{kg})$} \\
\hline & spectrometry HJ805-2016 & \\
\hline Benzo $[\mathrm{b}]$ & Gas chromatography-mass & \multirow{2}{*}{$0.05(\mathrm{mg} / \mathrm{kg})$} \\
\hline fluoranthene & spectrometry HJ805-2016 & \\
\hline \multirow{2}{*}{ fluoranthene [k] } & Gas chromatography-mass & \multirow{2}{*}{$0.05(\mathrm{mg} / \mathrm{kg})$} \\
\hline & spectrometry HJ805-2016 & \\
\hline \multirow[t]{2}{*}{ chrysene } & Gas chromatography-mass & \multirow{2}{*}{$0.05(\mathrm{mg} / \mathrm{kg})$} \\
\hline & spectrometry HJ805-2016 & \\
\hline Dibenzo $[\mathrm{A}, \mathrm{H}]$ & Gas chromatography-mass & \multirow{2}{*}{$0.05(\mathrm{mg} / \mathrm{kg})$} \\
\hline anthracene & spectrometry HJ805-2016 & \\
\hline Indene and & Gas chromatography-mass & \multirow{2}{*}{$0.05(\mathrm{mg} / \mathrm{kg})$} \\
\hline$[1,2,3-\mathrm{CD}]$ pyrene & spectrometry HJ805-2016 & \\
\hline \multirow{2}{*}{ Naphthalene } & Gas chromatography-mass & \multirow{2}{*}{$0.03(\mathrm{mg} / \mathrm{kg})$} \\
\hline & spectrometry HJ805-2016 & \\
\hline
\end{tabular}

\section{Results and Discussions}

\subsection{Criteria for Evaluation}

The selection of soil risk screening criteria is mainly based on the future use of the site. Site risk assessment and screening criteria are the basic basis for whether there is environmental risk in the site during the preliminary screening stage[3]. At present, China has issued the risk assessment and screening standards for construction land sites, namely, Soil Environmental Quality Soil Pollution Risk Control Standards for Construction Land (GB36600-2018). The area where the survey site is located is planned as a reserve place for development, and this survey adopts the construction land standard for evaluation[4]. The pollutants that may be involved in this site mainly include heavy metals, partial volatile and semi-volatile organic compounds, etc. In this investigation, the standard of "Class II industrial land" is preferentially selected as the screening standard of this site.

\subsection{Test Results and Discussion of Soil Samples}

Ten soil sampling sites were set up for this soil pollution survey, and a total of 24 soil samples were collected, including 24 heavy metal samples, 24 semi-volatile organic soil samples and 24 volatile organic soil samples for laboratory analysis.

Heavy metals in copper, lead, cadmium, nickel, arsenic, mercury and other six indicators have been detected, the detection value does not exceed the selected standard. Hexavalent chromium was not detected. In semi-volatile organic compounds (SVOC), benzo [a] anthracene, benzo [a] pyrene, benzo [b] fluoranthene, benzo [k] fluoranthene, dibenzo $[\mathrm{a}, \mathrm{h}]$ anthracene, indene [1,2,3-cd] pyrene, naphthalene were detected in some samples, and the detection values did not exceed the selected standard. Nitrobenzene, aniline and 2-chlorophenol were not detected. Volatile organic compounds (VOC) in carbon tetrachloride, chloroform, methyl chloride, 1,1-dichloroethane, 1,2-dichloroethane, 1,1-2vinylchloride, 1,2-2vinylchloride, anti-1,2-vinylchloride, methylenechloride, 1,2-2chlorop ropane, say-tetrachloroethane, 1,1,2,2-tetrachloroethane, tet rarchloroethylene, 1,1,1-trichloroethane, 1,2-trichloroethane, trichloroethylene, 1,2,3-3-chloropropane, vinyl chloride, benzene, chlorobenzene, 1,2-dichlorobenzene, 1,4-dichlorobenzene, ethylbenzene, styrene, toluene, $\mathrm{m}$-xylene $+\mathrm{p}$-xylene, o-xylene and other 27 indicators were not detected.

The low $\mathrm{pH}$ value of soil samples at some sampling points is related to the fact that the sample soil contains a small amount of pyrite[5]. According to the $\mathrm{pH}$ values of soil samples at different depths at the same point, only the measured values of some samples were low, so it was not determined to be caused by sulfuric acid pollution.

Table 3: Detection and evaluation of heavy metals and semi-volatile organic compounds (SVOC) in soil samples

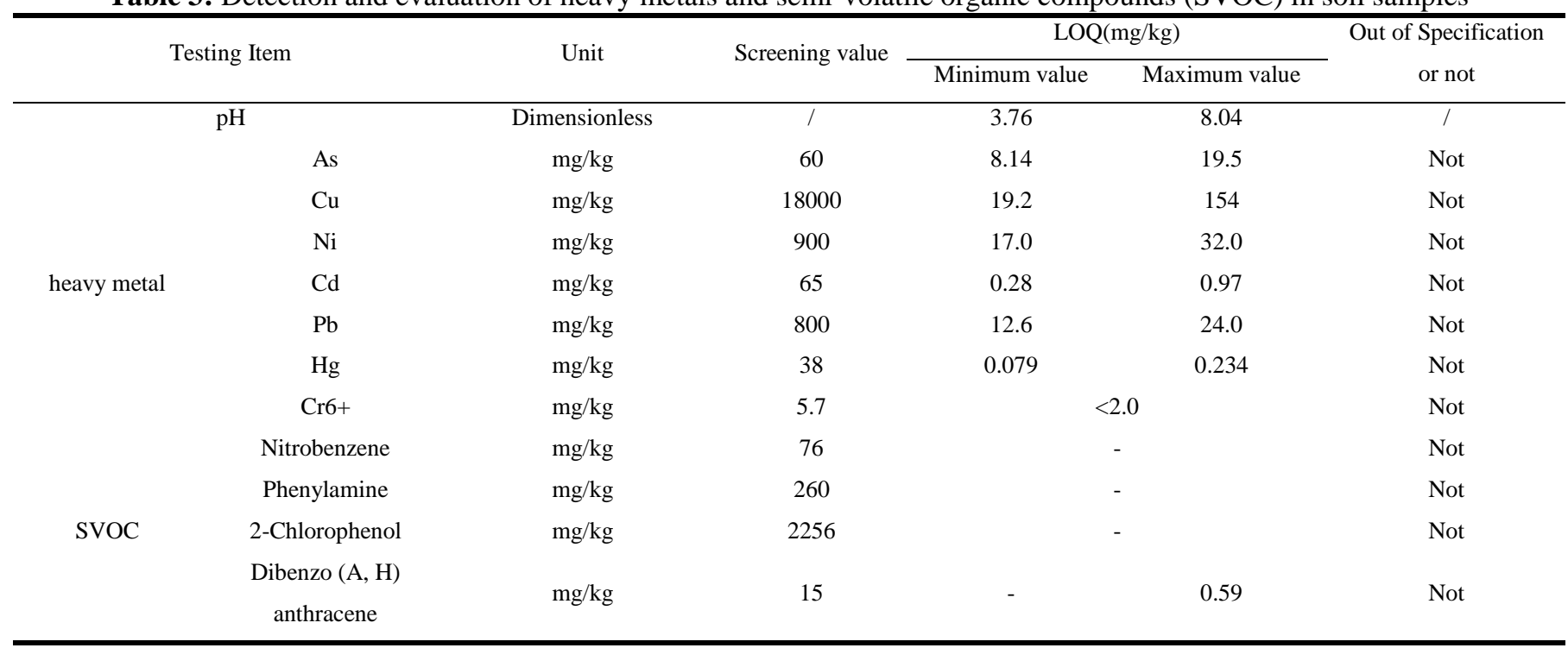




\begin{tabular}{|c|c|c|c|c|c|}
\hline $\begin{array}{c}\text { Benzo [b] } \\
\text { fluoranthene }\end{array}$ & $\mathrm{mg} / \mathrm{kg}$ & 15 & - & 0.81 & Not \\
\hline $\begin{array}{c}\text { Benzo }[\mathrm{K}] \\
\text { fluoranthene }\end{array}$ & $\mathrm{mg} / \mathrm{kg}$ & 151 & - & 0.3 & Not \\
\hline Benzo [a] pyrene & $\mathrm{mg} / \mathrm{kg}$ & 1.5 & - & 0.54 & Not \\
\hline Chrysene & $\mathrm{mg} / \mathrm{kg}$ & 1293 & - & 0.58 & Not \\
\hline $\begin{array}{c}\text { Dibenzo }[\mathrm{A}, \mathrm{H}] \\
\text { anthracene }\end{array}$ & $\mathrm{mg} / \mathrm{kg}$ & 1.5 & - & 0.18 & Not \\
\hline $\begin{array}{c}\text { Indene }[1,2,3-\mathrm{C}, \mathrm{D}] \\
\text { pyrene }\end{array}$ & $\mathrm{mg} / \mathrm{kg}$ & 15 & - & 0.61 & Not \\
\hline Naphthalene & $\mathrm{mg} / \mathrm{kg}$ & 70 & & & Not \\
\hline
\end{tabular}

Table 4: Detection and evaluation of volatile organic compounds (VOC) in soil

\begin{tabular}{|c|c|c|c|c|}
\hline Testing Item & Unit & Screening value & LOQ & Out of Specification or not \\
\hline $\begin{array}{l}\text { Carbon tetrachloride, chloroform, methyl chloride, 1,1-dichloroethane, } \\
\text { 1,2-dichloroethane, 1,1-2 vinyl chloride, 1,2-2 vinyl chloride, methylene } \\
\text { chloride, 1,2-chloropropane, say-tetrachloroethane, 1,1,2,2-, 1,1 tetrachloro } \\
\text { ethane, 1-trichloroethane, 1,2,1-trichloroethane, trichloroethylene and 1,2,3- } \\
\text { chloropropane, chloroethylene, benzene, chlorobenzene, 1,2-dichlorobe } \\
\text { nzene, 1,4-dichlorobenzene, ethylbenzene, styrene, toluene, m-xylene+ } \\
\text { p-xylene, o-xylene }\end{array}$ & $\mathrm{mg} / \mathrm{kg}$ & 0.05 & - & Not \\
\hline Tetrachloroethylene, trans-1,2-dichloroethylene & $\mathrm{mg} / \mathrm{kg}$ & 0.1 & - & Not \\
\hline $\begin{array}{l}\text { 3.3 Test Results and Discussion of Groundwater Samples } \\
\text { This plot groundwater quality on the basis of test results, }\end{array}$ & \multicolumn{4}{|c|}{$\begin{array}{l}\text { oxygen consumption, ammonia nitrogen indicators such as V } \\
\text { type of groundwater, sulfate content and soluble solids } \\
\text { content is higher, should not be directly as a drinking water } \\
\text { source, other water could be selected according to the } \\
\text { purpose. }\end{array}$} \\
\hline
\end{tabular}

Table 5: Detection items and evaluation of groundwater samples

\begin{tabular}{|c|c|c|c|c|c|}
\hline Testing Item & Testing result & Standard values & Unit & $\begin{array}{l}\text { Quality Control No. (Batch } \\
\text { No.) }\end{array}$ & $\begin{array}{c}\text { Evaluation of } \\
\text { the result }\end{array}$ \\
\hline $\mathrm{pH}$ & 4.15 & $4.13 \pm 0.05$ & dimensionless & GSB 07-3159-2014(202182) & Qualified \\
\hline Arsenic & 29.2 & $29.7 \pm 2.4$ & $\mathrm{ug} / \mathrm{L}$ & GSB $07-3171-2014(200442)$ & Qualified \\
\hline Cadmium & 0.143 & $0.149 \pm 0.008$ & $\mathrm{ug} / \mathrm{L}$ & GSB 07-3186-2014(200934) & Qualified \\
\hline Cr VI(chromium VI) & 0.303 & $0.299 \pm 0.011$ & $\mathrm{mg} / \mathrm{L}$ & GSB 07-3174-2014(203349) & Qualified \\
\hline Copper & 0.706 & $0.724 \pm 0.042$ & $\mathrm{mg} / \mathrm{L}$ & GSB 07-3186-2014(200934) & Qualified \\
\hline Plumbum & 0.294 & $0.297 \pm 0.012$ & $\mathrm{mg} / \mathrm{L}$ & GSB 07-3186-2014(200934) & Qualified \\
\hline Mercury & 5.20 & $5.15 \pm 0.42$ & $\mathrm{ug} / \mathrm{L}$ & GSB 07-3173-2014(202045) & Qualified \\
\hline Nickel & 0.180 & $0.177 \pm 0.010$ & $\mathrm{mg} / \mathrm{L}$ & GSB 07-3186-2014(200934) & Qualified \\
\hline Total hardness & 4.97 & $5.095 \pm 0.245$ & $\mathrm{mg} / \mathrm{L}$ & GSB 07-3185-2014(200619) & Qualified \\
\hline Total dissolved solids & 20.8 & $20.0 \pm 2$ & $\mathrm{~g} / \mathrm{L}$ & GBW (E)080970(1706) & Qualified \\
\hline Sulfate & 11.18 & $11.0 \pm 0.5$ & $\mathrm{mg} / \mathrm{L}$ & GSB07-1381-2001 & Qualified \\
\hline Chloride & 6.34 & $6.34 \pm 0.19$ & $\mathrm{mg} / \mathrm{L}$ & GSB07-1381-2001 & Qualified \\
\hline Fluoride & 1.51 & $1.5 \pm 0.07$ & $\mathrm{mg} / \mathrm{L}$ & GSB07-1381-2001 & Qualified \\
\hline $\begin{array}{l}\text { Permanganate index } \\
\text { (Oxygen consumption) }\end{array}$ & 2.29 & 2.31 & $\mathrm{mg} / \mathrm{L}$ & GSB 07-3162-2014(203183) & Qualified \\
\hline Ammonia nitrogen & 1.12 & $1.10 \pm 0.05$ & $\mathrm{mg} / \mathrm{L}$ & GSB 07-3164-2014(2005111) & Qualified \\
\hline Sodium $(\mathrm{Na})$ & 0.866 & $0.882 \pm 0.045$ & $\mathrm{mg} / \mathrm{L}$ & GSB 07-3185-2014(200619) & Qualified \\
\hline
\end{tabular}

\section{Conclusions and Recommendations}

\subsection{Conclusions}

Some indexes of heavy metals and semi-volatile organic compounds were detected in the soil samples tested in this plot, and the test results of each item did not exceed the screening value standard of category II land use in Soil Environmental Quality Soil Pollution Risk Control Standard for Construction Land (GB36600-2018). According to the test results and the Groundwater Quality
Standard (GB/T14848-2017), the $\mathrm{pH}$, total hardness, sulfate, dissolved solids, oxygen consumption, ammonia nitrogen and other indicators of groundwater quality in this block meet the $\mathrm{V}$ groundwater standard. The content of sulfate and dissolved solids is high, so it is not suitable to be directly used as drinking water source. Other water can be selected according to the purpose of use.

In conclusion, the preliminary investigation results of the contaminated site show that the concentration of heavy metals and volatile and semi-volatile pollutants in the soil of the site does not exceed the second-class land use screening value 
standard of the Soil Pollution Risk Control Standard for Soil Environmental Quality Construction Land (GB36600-2018).

Therefore, according to relevant regulations, the site is not a polluted site. The investigation of the soil environment can be concluded. There is no need to carry out detailed soil environment survey and health risk assessment.

\subsection{Recommendations}

(1) For the subsequent land development and utilization of the project, it is suggested to do a good job of supervision in the construction process according to the requirements of relevant documents.

(2) In the subsequent process of land development, if abnormal signs of soil and groundwater pollution are found, such as buried tanks, troughs, smelly wastes and other traces of pollution, the development site should be blocked immediately, and relevant departments should be notified immediately to organize on-site inspection.

\section{Acknowledgments}

This paper is supported by the following funds: National Key Research and Development Project (NO. 2019YFC1803501).

\section{References}

[1] Zheng Jingzhi, Wang Chudong, Wang Shihan, Lin Yuye, Zhao Keli, Wu Dongtao, Fu Weijun. Spatial heterogeneity and risk assessment of soil heavy metals in typical small cities: A case study of Lin'an City[J]. Environmental Science, 2018, 39(06): 2875-2883.

[2] Yang Xue, Xiaoming Liu. Detoxification, solidification and recycling of municipal solid waste incineration fly ash: A review[J]. Chemical Engineering Journal, 2021, 420: 130349.

[3] Hongju Zhang, Keli Zhao, Zhengqian Ye, Bin Xu, Weiming Zhao, Xiaobo Gu, Huafeng Zhang. Environmental Science, 2018, 39(06): 2893-2903.

[4] Chen Lihong, Huang Jinzhou, Tang Fei, Li Junheng. Investigation and risk assessment of heavy metal contaminated sites based on Guangdong $[\mathrm{J}]$. Energy Conservation and Environmental Protection, 2019(08): 24-25.

[5] Zhou Haoyu, Liu Zhong, Chen Haifeng, Hu Feiping, Wu Chunyang, Zhao Zhanqing. Investigation on soil pollution status of decommissioned sulphuric acid plant[J]. China Resources Comprehensive Utilization, 2021, 39(05): 125-128. 